\title{
Correction: Influence of digital banking channels on the number of branches in European Union countries and Serbia (2020, Vol. 56, No. 43, pp. 67-84)
}

Исправка: Утицај дигиталних банкарских канала на број филијала у земљама Европске уније и Србије (2020, вол. 56, 6р. 43, стр. 67-84)

\section{Editorial Board}

Abstract: In the paper "Influence of digital banking channels on the number of branches in the European Union and Serbia" by Maja Putica, published in no. 43 (year 56) of the journal Annals of the Faculty of Economics in Subotica, on page 74 , a wrong table was unintentionally published due to technical error, and on this occasion we apologize to the author and the readers. With the author's consent, in this issue we publish the corrected page of the text and Table 2 , which was originally supposed to be published on page 74 .

Table 2. Correlation matrix

\begin{tabular}{|c|c|c|c|c|c|}
\hline $\begin{array}{c}\text { Electronic } \\
\text { credit } \\
\text { transfers }\end{array}$ & $\begin{array}{c}\text { Debit/delayed } \\
\text { debit card } \\
\text { payments }\end{array}$ & $\begin{array}{c}\text { Credit } \\
\text { card } \\
\text { payments }\end{array}$ & $\begin{array}{c}\text { Direct } \\
\text { debit } \\
\text { payments }\end{array}$ & $\begin{array}{c}\text { ATM } \\
\text { transactions }\end{array}$ & $\begin{array}{c}\text { POS } \\
\text { transactions }\end{array}$ \\
\hline 1.00 & 0.60 & 0.30 & 0.86 & 0.58 & 0.79 \\
\hline 0.60 & 1.00 & 0.90 & 0.55 & 0.99 & 0.84 \\
\hline 0.30 & 0.90 & 1.00 & 0.33 & 0.89 & 0.70 \\
\hline 0.86 & 0.55 & 0.33 & 1.00 & 0.53 & 0.82 \\
\hline 0.58 & 0.99 & 0.89 & 0.53 & 1.00 & 0.83 \\
\hline 0.79 & 0.84 & 0.70 & 0.82 & 0.83 & 1.00 \\
\hline
\end{tabular}

Source: the author's calculation

Keywords: number of branches, digital banking channels, multivariate analysis, European Union, Serbia JEL classification: G21, M31

Сажетак: У раду ауторке Маје Путица под насловом „Утицај дигиталних банкарских канала на број филијала у земљама Европске уније и Србије“ (енг. Influence of digital banking channels on the number of branches in European Union countries and Serbia) објављен у бр. 43 (год. 56) часописа Анали Економског факултета у Суботици, на страници 74, техничком грешком објављена је погрешна табела, те се овом приликом извињавамо ауторки и читаоцима. Уз сагласност ауторке, у овом броју објављујемо исправљену страницу текста и табелу 2 која је првобитно требала да се налази на страници 74. 
Table 2. Correlation matrix

\begin{tabular}{|c|c|c|c|c|c|}
\hline $\begin{array}{c}\text { Electronic } \\
\text { credit } \\
\text { transfers }\end{array}$ & $\begin{array}{c}\text { Debit/delayed } \\
\text { debit card } \\
\text { payments }\end{array}$ & $\begin{array}{c}\text { Credit } \\
\text { card } \\
\text { payments }\end{array}$ & $\begin{array}{c}\text { Direct } \\
\text { debit } \\
\text { payments }\end{array}$ & $\begin{array}{c}\text { ATM } \\
\text { transactions }\end{array}$ & $\begin{array}{c}\text { POS } \\
\text { transactions }\end{array}$ \\
\hline 1.00 & 0.60 & 0.30 & 0.86 & 0.58 & 0.79 \\
\hline 0.60 & 1.00 & 0.90 & 0.55 & 0.99 & 0.84 \\
\hline 0.30 & 0.90 & 1.00 & 0.33 & 0.89 & 0.70 \\
\hline 0.86 & 0.55 & 0.33 & 1.00 & 0.53 & 0.82 \\
\hline 0.58 & 0.99 & 0.89 & 0.53 & 1.00 & 0.83 \\
\hline 0.79 & 0.84 & 0.70 & 0.82 & 0.83 & 1.00 \\
\hline
\end{tabular}

Source: the author's calculation

Кључне речи: број филијала, дигитални банкарски канали, мултиваријациона анализа, Европска унија, Србија

JEL класификација: G21, M31 